\title{
INVESTMENT ATTRACTIVENESS OF AGRICULTURAL ENTERPRISES
}

\author{
Nadiia Davydenko ${ }^{1}$ Prof. dr hab.; Halyna Skrypnyk ${ }^{2} \mathrm{PhD}$ and Zoya Titenko ${ }^{3} \mathrm{PhD}$ \\ $1,2,3$ National University of Life and Environmental Science of Ukraine
}

\begin{abstract}
In today's economic development, attracting investment is one of the main ways and sources of development and expansion of agrarian enterprises. Investments play the most important role in the formation of enterprise resources. Therefore, the most important for a business entity is the creation of favourable conditions for investing by investors. The basis for an investor's investment decision is the level of investment attractiveness of an enterprise. For this purpose, analysts of farms should be able to professionally and accurately calculate the investment attractiveness of an enterprise based on the rating of the issuer, based on the definition of the financial state and the method of integrated assessment. The application of this approach allows the quick access to the prospects of investing funds and the reliability of the work of investment objects. At the same time, the investment potential of enterprises and investment risks are expressed as an integral indicator, which allows to estimate the investment attractiveness of enterprises. To test the results of the research, three joint-stock agricultural companies have been selected, located in different regions, the companies do not have the same investment climate and specialize in the cultivation of cereals and industrial crops. Based on the calculation of financial indicators, we have determined their investment attractiveness.

The proposed methodology for assessing the investment attractiveness of agricultural enterprises, which consists of calculating the integral indicator, will allows to explore all aspects of the activity and take into account a significant set of indicators. The mathematical tools of this technique will allow to standardize the indicators and reduce them to a homogeneous value, and ultimately rank the evaluated enterprises by the level of investment attractiveness. The practical application of the above recommendations will increase the objectivity of assessing the investment attractiveness of agricultural enterprises, will enable the investor to prove the expediency of investing in a particular country, region, industry or enterprise.
\end{abstract}

Key words: investment climate, investment attractiveness, agricultural enterprises, rating assessment, integral assessment.

JEL code: G31, L53, Q13, R51

\section{Introduction}

The purpose of the study is to substantiate and improve the methodological approaches to determining the investment attractiveness of agrarian enterprises, which corresponded to the needs of potential investors regarding the prospects of capital investment.

The main objectives of the study are: the disclosure of scientific approaches to the definition of investment attractiveness of enterprises; analysis of investment attractiveness of the region; rating of enterprises, based on the definition of financial condition; an integrated assessment of the investment attractiveness of agrarian enterprises, using an integrated approach taking into account a certain set of indicators.

Information sources: scientific articles available in international editions, annual financial reports of agrarian enterprises of Ukraine.

The most important task of the modern innovation policy of agricultural enterprises is to increase their investment attractiveness and to build a holistic financial support system for these purposes, which should be based on widespread attraction and the most efficient use of financial resources with diverse sources of origin. Investment attractiveness of enterprises is an integral characteristic from the point of perspective of their development, expansion of production and marketing parameters, strengthening the position on the market, the efficiency of the use of assets and their liquidity, solvency and financial sustainability, business activity, which in general can provide the appropriate level of competitiveness of object of management in the market. Particularly acute, the problem of increasing the investment attractiveness of the agricultural sector of the Ukrainian economy, which 
is significantly lagging behind in technical and technological development, has a number of peculiarities that determine the necessity of accelerating investment processes: the unsatisfactory state of the material and technical base, its inconsistency with the level of scientific and technological progress, market instability of agricultural products, financial problems of enterprises, low profitability of production. Therefore, the problems of determining the investment attractiveness of agricultural enterprises of Ukraine are now quite relevant, strategic in the light of the need for the future economic breakthrough of the agricultural economy and its output on a fundamentally new development trajectory.

\section{Research results and discussion}

Formation of the investment attractiveness of an agricultural enterprise, that is, ensuring the availability of such characteristics that determine the urgency of the issue of investment with the appropriate prospect of their return and multiplication, is a process that requires specific management influence.

The object of management is the financial and economic activity of the enterprise in terms of its results, which determine the attractiveness of the enterprise for investing and the factors that influence the obtaining of these results.

Proceeding from the principle of systemacity and complexity, the study of the investment attractiveness of agricultural enterprises requires the use of systematic approach, that is, in order to analyse the investment attractiveness of agricultural enterprises. Firstly, it is necessary to give a general description of the investment climate of the country and region to which the enterprise belongs, and secondly to analyse the level of development of the agricultural sector, and then consider the main indicators of the work of agricultural enterprises, which affect their investment attractiveness. Some scholars, in particular, Blank I. (2004), Koyda V., Lepekiko T. (2008), and Gaidutsky A. (2004) believe that "investment attractiveness" is an integral characteristic of the enterprise in terms of the efficiency of the use of assets and their liquidity, I will have solvency and financial stability. In turn, Bocharov V. (2000), Stechko D. (2001), and Chornaya L. (2008), in their works, consider "investment attractiveness" as a qualitative characteristic of the investment climate. A slightly different view is expressed by Napadovskaya I. (2005) and Asaul A. (2004), they represent "investment attractiveness" as a set of conditions that influence the formation of an investment climate.

We believe that each of the above definitions allows you to highlight only a part of the relationships and characteristics inherent in the investment attractiveness at the level of the individual entity.

In our opinion, a more complete and refined concept of investment attractiveness is the following definition: investment attractiveness of the enterprise - is an integral characteristic of the company as a future investment object, taking into account the combination of factors of external and internal influence, prospects of development and the possibility of attracting investment resources.

In domestic practice, it is possible to distinguish the following methods for assessing the investment attractiveness of enterprises:

- the method of rating company's valuation based on the data of financial statements, which provides an assessment of the financial condition of the enterprise, which assesses solvency, financial stability, profitability and business activity of the enterprise;

- integral assessment of investment attractiveness, approved by the order of the Agency For The Prevention Of Bankruptcy Of Enterprises And Organizations. It involves defining an integral indicator of the investment attractiveness of the enterprise, which includes: integral indicator of property 
status, financial stability, profitability, business activity, asset liquidity, as well as market activity of the invested object.

We will conduct a study on the investment attractiveness of the enterprises on the example of three agricultural enterprises from different regions of Ukraine with different indicators of the financial state: PJSC „Iskra”, PJSC "Im. Shevchenko" and PJSC "Kagarlyzke". For a more accurate and unbiased assessment, we have compared the agricultural enterprises of one organizational and legal form, called private joint-stock companies (Table 1).

Table 1

Receipt and development of investments in the studied regions of Ukraine

\begin{tabular}{|l|c|c|c|}
\hline \multirow{2}{*}{ Region } & \multicolumn{2}{|c|}{$\begin{array}{c}\text { Volume of developed } \\
\text { investments in the region }\end{array}$} & \multicolumn{1}{c|}{$\begin{array}{c}\text { Investigated } \\
\text { enterprise }\end{array}$} \\
\cline { 2 - 4 } & thousand UAH & in \% to the total volume & \\
\hline Sumy region & 2726306 & 39.2 & PJSC «Iskra» \\
\hline $\begin{array}{l}\text { Cherkasy } \\
\text { region }\end{array}$ & 3178515 & 39.0 & PJSC «Imeni Shevchenko» \\
\hline Kyiv region & 4662796 & 13.5 & PJSC «Kagarlyzke» \\
\hline
\end{tabular}

Source: author's calculations

The investment attractiveness of a particular company depends directly on the investment climate and investment potential of the region. Determining the investment attractiveness of the region is important for many structures. To predict the investment attractiveness of the whole region, the rating agency "Euro-Rating" annually makes the rating of investment efficiency of the regions of Ukraine. Below we have considered the rating of the studied areas (Table 2).

Table 2

Ratings of investment efficiency of the studied regions of Ukraine

\begin{tabular}{|l|c|c|c|c|c|c|c|c|}
\hline \multirow{2}{*}{ Region } & \multicolumn{2}{|c|}{$\mathbf{1}$ half of $\mathbf{2 0 1 7}$} & \multicolumn{2}{c|}{$\mathbf{2}$ half of $\mathbf{2 0 1 7}$} & \multicolumn{2}{c|}{$\mathbf{1}$ half of $\mathbf{2 0 1 8}$} & \multicolumn{2}{c|}{$\mathbf{2}$ half of $\mathbf{2 0 1 8}$} \\
\cline { 2 - 10 } & Rating & Point & Rating & Point & Rating & Point & Rating & Point \\
\hline $\begin{array}{l}\text { Kyiv } \\
\text { region }\end{array}$ & ineC & 173 & ineC & 179 & ineA & 203 & ineA & 234 \\
\hline $\begin{array}{l}\text { Sumy } \\
\text { region }\end{array}$ & ineE & 122 & ineC & 170 & ineG & 72 & ineF & 101 \\
\hline $\begin{array}{l}\text { Cherkasy } \\
\text { region }\end{array}$ & ineD & 153 & ineC & 173 & neD & 159 & neD & 147 \\
\hline
\end{tabular}

Source: author's calculations

According to rating data, there is an improvement in the investment attractiveness of the Kyiv region. Negative aspect is the reduction of the attractiveness of the Sumy region from ineE to ineF and Cherkasy from ineC to ineD. The most attractive region is the Kyiv, and the least attractive - the Sumy region. This is due to certain factors that influence the formation of investment potential, namely the level of attractiveness of the priority sectoral industries, the state and dynamics of the investment market.

Based on the indicators of financial reporting, we will determine the investment attractiveness of agricultural enterprises (Table 3). The financial condition of the investigated enterprises is different. The worst indicators are in PJSC "Iskra". An enterprise is not financially sustainable and is unprofitable. The net loss in 2017 amounted to almost UAH 47 million. The company should urgently hold a series of measures to prevent the bankruptcy proceedings.

Better indicators are at PJSC "Kagarlyzke". The enterprise is financially sustainable and solvent. The negative aspect is the availability of 2 million UAH loss in 2017, however, with proper fiscal policy, the company will be able to have the net profit. 
Rating estimation of investment attractiveness of agricultural enterprises, 2017

\begin{tabular}{|c|c|c|c|}
\hline Indicator & $\begin{array}{c}\text { PJSC } \\
\text { «Iskra» }\end{array}$ & $\begin{array}{l}\text { PJSC «Imeni } \\
\text { Shevchenko» }\end{array}$ & $\begin{array}{c}\text { PJSC } \\
\ll \text { Kagarlyzke» }\end{array}$ \\
\hline Total liquidity ratio & 0.2 & 25.2 & 4.0 \\
\hline Quick liquidity ratio & 0.03 & 24.4 & 3.3 \\
\hline Absolute liquidity ratio & 0.01 & 0.1 & - \\
\hline The coefficient of financial stability & -0.5 & 1.0 & 0.8 \\
\hline Coefficient of financial risk (financial leverage) & -3.1 & 0.04 & 0.3 \\
\hline Total solvency ratio & 0.7 & 26.4 & 4.1 \\
\hline Current solvency ratio & 0.01 & 0.1 & - \\
\hline Asset turnover rate & 0.5 & 0.2 & 0.5 \\
\hline Reserve turnover rate & 9.1 & 10.8 & 15.1 \\
\hline Cost-effectiveness of production, $\%$ & -11.9 & 107.0 & -5.6 \\
\hline Return on assets, \% & -3.8 & 32.1 & -2.2 \\
\hline Return on equity capital, \% & -5.4 & 33.5 & -2.7 \\
\hline Place in rating & 3 & 1 & 2 \\
\hline Estimation of financial condition & $\begin{array}{c}\text { unprofitable, } \\
\text { unsatisfactory } \\
\text { state }\end{array}$ & $\begin{array}{c}\text { Liquid, } \\
\text { financially } \\
\text { sustainable }\end{array}$ & $\begin{array}{c}\text { satisfactory, } \\
\text { financially } \\
\text { sustainable }\end{array}$ \\
\hline
\end{tabular}

Source: author's calculations

The best financial condition of the research results is in PJSC "Im. Shevchenko". The company is solvent, liquid and financially sustainable. The net profit in 2017 amounted to about 32 million UAH, and the return on equity was $33 \%$.

We will evaluate the investment attractiveness of the investigated enterprises by the integral indicator of the investment attractiveness of the enterprise.

This methodology for an integrated assessment of the investment attractiveness of enterprises and organizations involves the calculation of 6 groups of indicators: valuation of property status; assessment of financial stability (solvency); liquidity assessment of assets; assessment of profitability; assessment of business activity; evaluation of market activity by the formula:

$$
I=\Sigma \text { fjms }+ \text { fjfs }+ \text { fjpr }+ \text { fjda }+ \text { fjla }+ \text { fjra }
$$

$I$ - integral indicator of investment attractiveness of the enterprise, fjms, fjfs, fjpr, fjda, fjla, fjra - weight coefficients of integral indicators of property status, financial stability, profitability, business activity, asset liquidity, market activity of the invested object. 
Estimation of investment attractiveness by the integral estimation method

\begin{tabular}{|l|c|c|l|}
\hline Enterprise & $\begin{array}{c}\text { The } \\
\text { amount } \\
\text { of points }\end{array}$ & Method of calculation & \multicolumn{1}{c|}{ Result } \\
\hline PJSC «Iskra» & 21.68 & $\begin{array}{c}\mathrm{I}=4.95-26.52+27.38- \\
9.63+37.71-12.21\end{array}$ & $\begin{array}{l}\text { Investment attractiveness is low. An } \\
\text { enterprise does not pay dividends. In order } \\
\text { to attract investors, the economy needs to } \\
\text { carry out a number of measures for the } \\
\text { financial rehabilitation of the enterprise }\end{array}$ \\
\hline $\begin{array}{l}\text { PJSC «Imeni } \\
\text { Shevchenko» }\end{array}$ & 242.77 & $\begin{array}{l}\text { I }=11.11+61.71+143.43- \\
4.26+41.21-10.41\end{array}$ & $\begin{array}{l}\text { The enterprise is an investment attractive. } \\
\text { High indicators of financial condition, } \\
\text { sTable income level enable to attract not } \\
\text { only domestic but also foreign investments }\end{array}$ \\
\hline $\begin{array}{l}\text { PJSC } \\
\text { «Kagarlyzke» }\end{array}$ & 87.89 & $\mathrm{I}=9.05+14.20+15.29-$ & $\begin{array}{l}\text { Investment attractiveness of enterprises at } \\
\text { an adequate level. The investment of funds } \\
\text { will allow the company to exit in the next } \\
\text { reporting period to a positive financial result }\end{array}$ \\
\hline
\end{tabular}

As a result of the analysis, the investment attractiveness of PJSC "Im. Shevchenko" with a score of 242,77 points is on the first place. The second place goes to PJSC "Kagarlyzke" with the result of 87,89 points. And the worst result has PJSC "Iskra" with only 21,68 points. That is, for the investor the best decision is to invest in the company PJSC "Im. Shevchenko".

\section{Conclusions, proposals, recommendations}

1) The main identifier of the appropriateness of investing funds for an investor is the investment attractiveness of the enterprise. It means the characteristics of the future investment object from the standpoint of assessing its financial status, competitiveness, image and other factors of external and internal influence, which are crucial for the investor. The investment attractiveness of a particular company depends directly on the investment climate and investment potential in the region. Investigating the investment attractiveness of regions according to the region's rating, points out that the most attractive region is the Kiev, less attractive - Cherkassy and least attractive - Sumy region.

2) In assessing the investment attractiveness of the issuer's rating, we note that the financial status of the investigated enterprises is different. The worst performance is in the Iskra PJSC, which is located in the Sumy region. The enterprise is unsatisfactory and is unprofitable. Somewhat better indicators at PJSC "Kagarlyk", which is located in the Kyiv region and has a satisfactory financial condition. The best financial condition of the research results is PJSC "Im. Shevchenko ", which is located in Cherkasy region. The company is solvent, liquid and financially sustainable.

3) In assessing the investment attractiveness of farms by the integrated analysis method, the investment attractiveness of PJSC Iskra, the investment attractiveness at PJSC Kagarlyk, and the most attractive are PJSC "Im. Shevchenko ". Analysing the foregoing, we note that both methods of assessing the investment attractiveness of agrarian enterprises have shown the same results. Except internal factors, the investment attractiveness is influenced by external ones, namely the location in the respective region. As a result, the enterprise of PJSC "Iskra", which is in the least attractive region - Sumy region, has the smallest investment attractiveness.

4) The analysis of the investment attractiveness of the region and enterprises by the issuer's rating and the integral assessment method is important for the external investor as the probability of making false investment decisions is rather high. Based on the analysis of investment attractiveness, it is possible to prove to the investor the expediency of investing in a particular 
region, enterprise. The extent to which this assessment is objectively and comprehensively carried out, and consequently, the proper follow-up of the feasibility of investing depends on the final result that the investor will receive.

\section{Bibliography}

1. Bocharov V. (2000). Investment Management. St. Petersburg.

2. Blank I. (2004). Investment Management Company. Kiev.

3. Gaiducky A. (2004). Methodological Aspects of the Investment Attractiveness of the Economy. Regional Economy. 4. p. 81-86.

4. Napadovskaya I. (2005). Theoretical and Methodological Aspects of Research of Investment Attractiveness of Ukraine. Herald DonDouet. 4. p. 55-61.

5. Koyda V., Lepekiko T., Koydu O. (2008). Fundamentals of Investment Management. Kiev.

6. Stechko D. (2001). Placement of Productive Forces and Regionalistics. Kiev.

7. Chorna L. (2008). Effective Strategy to Achieve the Investment Attractiveness of the Enterprise. Investments: Practice and Experience. Volume 24. p. 4-6.

8. Asaul A. (2004). Systematization of Factors Characterizing the Investment Attractiveness of the Regions. Regional Economy. 2. p. 53 - 62.

9. On Approval of the Methodology of Integral Assessment of Investment Attractiveness of Enterprises and Organizations: Order of the Agency for the Prevention of Bankruptcy of Enterprises and Organizations of 31.03.1998 - [Electronic Resource] - Access Mode: https://zakon.rada.gov.ua/laws/show / z0214-98

10. The Official Website of the EuroRating Rating Agency. - [Electronic resource] - Access mode: http://eurorating.com.ua/regiony/rejting-list/rejting-list-oblastej/ 